\section{Effect of Grafting on Growth, Yield, and Verticillium Wilt of Eggplant}

\author{
Fotios Bletsos ${ }^{1}$ \\ NAGREF, Agricultural Research Center of Macedonia and Thrace, Department \\ of Vegetables, P.O. Box 60458, GR-570 01 Thermi-Thessaloniki, Greece
}

Costas Thanassoulopoulos

Aristotle University of Thessaloniki, Faculty of Agriculture, Plant Pathology Laboratory, 54006 Thessaloniki, Greece

\section{Demetrios Roupakias}

Aristotle University of Thessaloniki, Faculty of Agriculture, Genetics and Plant Breeding Laboratory, 54006 Thessaloniki, Greece

Additional index words. Solanum species, rootstock, economic value

Abstract. Eggplant (Solanum melongena L.) seedlings ('Tsakoniki') were grafted by hand on the Verticillium dahliae Kleb. resistant wild species Solanum torvum Sw. (GST) and Solanum sisymbriifolium Lam. (GSS). Grafted and nongrafted eggplants were transplanted to a fumigated soil with methyl bromide and to infested soil with microsclerotia of $V$. dahliae. Grafted plants were more vigorous, as measured by plant height, main stem diameter, and root system weight, than the nongrafted 'Tsakoniki'. This resulted in an increased early production (GST, 45.5\% ; GSS, 18.4\%) and late production (GST, 69.3\%; GSS, $59.2 \%$ ) as compared to the noninfected controls. The mean yield reduction (over years) in early production caused by the disease, as compared to the controls grown in fumigated soil, was $29.4 \%, 36.6 \%$, and $77.9 \%$ for eggplant grafted on S. torvum, S. sisymbriifolium, and nongrafted plants, respectively. This yield reduction in total production was $6.9 \%, 20.5 \%$, and $56.8 \%$, respectively. The disease incidence in ungrafted plants was $96 \%$ and $100 \%$ during early and late harvest periods. In contrast, the disease incidence in grafted plants was significantly lower, averaging $28.1 \%$ (GST) and $52.6 \%$ (GSS) in early production, and $37.6 \%$ and $79.3 \%$, respectively, in late production. Solanum torvum was found more resistant than $S$. sisymbriifolium, because grafted infected plants developed mild symptoms, as indicated by significantly lower leaf symptom index (average value 1.2 and 2.22) and disease index (average value 1.55 and 3.38), respectively. In conclusion, grafting of eggplant on either wild species had positive effects on growth, production, and verticillium wilt control.

Verticillium wilt, caused by Verticillium dahliae Kleb., is one of the most destructive diseases of eggplant, causing an estimated yield reduction of up to $50 \%$ (Bletsos et al., 1997a). Symptoms of this disease are yellow-bronze wilted areas, mainly between the leaf veins, and vascular discoloration. Plant growth (O' Brien, 1983) and fruit yield and quality are reduced (Bletsos et al., 1999). Continuous cropping of eggplant is commonplace in greenhouses. More than $68 \%$ of the failure in Japanese vegetable production under continuous cropping has been ascribed to diseases caused by soilborne pathogens, primarily verticillium wilt (Takahashi, 1984, referred by Oda et al., 1997). In greenhouse cultivation, verticillium wilt is controlled by soil fumigation with methyl bromide. Methyl bromide is considered a dangerous air pollutant

Received for publication 10 Sept. 2001. Accepted for publication 23 June 2002. Financial assistance from the general secretariat for research and technology is gratefully acknowledged. The authors are indebted to Mrs. Maria Thanassoulopoulou, teacher of English, for editing the English draft.

${ }^{1}$ To whom reprint requests should be addressed. Tel. +00 302310 471544; fax +00 302310 471209; e-mail address: fbletsos@nagref.gr because of its effect on the ozone layer. It is both toxic to humans and animals during its application and dissipation periods (Ristaino and Tomas, 1997) and has been detected in groundwater (Wheeler and Kawar, 1997). For these reasons, 168 countries, including Greece (1997), have agreed to gradually reduce methyl bromide production and to phase out its use in agriculture by the year 2005 .

Grafting plants on resistant rootstock could be an alternative control of soilborne diseases. Grafting watermelon on gourd rootstock has been used for protection from Fusarium wilt since the 1900s. Grafting has been expanded to other vegetables, including melon, cucumber, tomato, and eggplant) (Lee, 1994; Oda, 1995). Thus, Ferrari (1998) grafted melon to control Fusarium oxysporum f. sp. melonis and Klose et al. (1980) grafted cucumber to control $F$. oxysporum f. sp. cucumerinum. Grafting susceptible tomato cultivars on resistant $F_{1}$ tomato hybrid rootstock type KVFN was an economic method of controlling verticillium and fusarium wilt, corky root (Pyrenochaeta lycopersici), and root-knot nematodes (Meloidogyne sp.) (Ginaux et al., 1979).

All commercial eggplant cultivars are susceptible to verticillium wilt. Furthermore, production and breeding for resistance has been difficult (Kalloo, 1993; Nicklow, 1983). Grafting eggplant on resistant tomato rootstocks was found an effective control method for verticillium wilt (Ginaux and Douple, 1985; Lockwood et al., 1970). The wild species Solanum torvum Sw. and Solanum sisymbriifolium Lam. are resistant to verticillium wilt(Alconero et al., 1988; Sakata et al., 1989). Susceptible eggplants were grafted on rootstock of scarlet eggplant (Solanum integrifolium Poir.) early in the 1950s with satisfactory results (Yamakawa, 1983, referred by Oda, 1995). Since then, the cultivation of grafted fruit-bearing vegetable plants has increased greatly. Grafting of eggplant on S. torvum, which grows in tropical and subtropical areas and has a vigorous root system and vegetative growth (Tachibana, 1994), is extensively used in the vegetable industry in Japan (Sakata et al., 1989), accounting for $50 \%$ of the total acreage (Oda, 1995). There are no reports on the effectiveness of grafting eggplant on S. sisymbriifolium.

Disadvantages of grafting are the required time, space, materials, and high labor costs. Sometimes the incompatibility between rootstocks and scions also reduces fruit quality (Oda, 1995). In Greece, grafting of vegetables is practiced in the south, where early watermelon, melon, and eggplant are grown under low plastic tunnels. About $5 \%$ to $10 \%$ of the tunnels are planted with grafted eggplant. Grafting is considered an important technique for the sustainable production of fruit-bearing vegetables.

The present work was undertaken to investigate the agronomic behavior of the most important Greek eggplant cultivar, 'Tsakoniki', when grafted on rootstocks of $S$. torvum and S. sisymbriifolium.

\section{Materials and Methods}

The experiments were carried out during 1998 and 1999 at the Agricultural Research Centre of Macedonia and Thrace, Greece. The soil was a sandy loam and had a pH of 7.25, free $\mathrm{CaCO}_{3}=2.65 \%$, organic matter $1.75 \%$, electric conductivity $3.12 \mathrm{mmhos} / \mathrm{cm}$, Olsen's phosphorus $>200 \mathrm{ppm}$, and exchangeable potassium $895 \mathrm{ppm}$

The Greek eggplant ‘Tsakoniki’ was planted in soil artificially infested with $V$. dahliae. Isolates of $V$. dahliae from tomato, potato, and eggplant were grown on potato dextrose agar and were used in a mixture (1:1:1) throughout. Inoculum was prepared by growing each isolate for $8 \mathrm{~d}$ at $20 \pm 2{ }^{\circ} \mathrm{C}$ in plastic petri dishes, 5.5 $\mathrm{cm}$ in diameter. A quantity of $\approx 5 \mathrm{~mL}$ of sterile distilled water was added per dish and the colonies were scarped with a sterilized needle. The contents of each dish were filtered through cheesecloth; the filtrates were combined; and the inoculum suspension consisted of microconidia adjusted to $10^{6}$ spores $/ \mathrm{mL}$. Five milliliters of the above inoculum suspension was used to inoculate a 1-L glass jar containing $200 \mathrm{~g}$ growth medium made of 1 cornmeal: 1 perlite: 4 water (by weight). The jars were kept at 20 $\pm 2{ }^{\circ} \mathrm{C}$ and the fungus grew during the first $7 \mathrm{~d}$ at daylight; then they were covered with black plastic during the following $23 \mathrm{~d}$ in order to 
promote microsclerotia production (Bletsos et al., 1997b).

In the first year (1998) the soil was fumigated with methyl bromide $98 \%$-chloropicrin $2 \%$ (by weight) (Bromine Compounds Ltd., Israel) at the rate of $68 \mathrm{~g} \cdot \mathrm{m}^{-2}$. A total of $200 \mathrm{~g}$ of inoculum containing $15 \times 10^{4}$ microsclerotia/g (Bardas, unpublished data) was used to infest each hill in one field. The other noninfested field, where the controls were planted, was fumigated in both years. Eggplants, $30 \mathrm{~d}$ old, were grafted (on the first week of April each year) onto rootstock from plants of the wild species S. torvum (50 d old) and S. sisymbriifolium (30 d old), applying the cleft grafting method (Oda, 1995). Thirty days later the grafted and nongrafted seedlings were transplanted. The experiment was a two-factor factorial trial with soil treatments (soil fumigated, and soil fumigated + infested with $V$. dahliae) and rootstock treatments (grafting on $S$. torvum, grafting on S. sisymbriifolium, and nongrafting). Analysis of variance was performed with MSTAT-C program. The treatments were arranged in a randomized complete-block design with three replications for each treatment (infested and noninfested soil). There were 10 or seven plants per replication in 1998 and 1999, respectively. The distance between rows was $100 \mathrm{~cm}$, and among hills within the row was $50 \mathrm{~cm}$. The percentage of infection was converted by square root transformation $\sqrt{\mathrm{x}+0.5}$ prior to statistical analysis.

A leaf symptom index (LSI), ranging from 1 to $6(1=$ apparently healthy plants; $2=$ slight chlorosis of the lower leaves, erratic interveinal yellow-bronze wilted area; $3=$ leaf spot necrosis, defoliation of lower leaves, yellow-bronze

Table 1. Mode of calculation of verticillium wilt index.

\begin{tabular}{lccc}
\hline LSI $^{\mathrm{z}}$ & VDI $^{\mathrm{y}}$ & LSI $\times$ VDI & DI $^{\mathrm{x}}$ \\
\hline 1 & 1 & 1 & 1 \\
2 & 2 & 2 & 2 \\
3 & 3 & $3,4,5$ & 3 \\
4 & 4 & $6,8,9$ & 4 \\
5 & & $10,12,15$ & 5 \\
6 & & $16,18,20,24$ & 6 \\
\hline
\end{tabular}

${ }^{2}$ LSI = Leaf symptom index.

${ }^{y} \mathrm{VDI}=$ Vascular discoloration index.

${ }^{x} \mathrm{DI}=$ Disease index.

The numbers $7,11,13,14,17,19,21,22$, and 23 can not exist as products of columns 1 and 2 . wilted area in the upper leaves, slight wilt; $4=$ serious wilt, lower leaves dead, partial death of plants, extensive defoliation, discoloration of the petiole vascular tissue in the upper leaves; $5=$ plants with a leaf tassel only on the top, clear vascular discoloration in the upper part of the stem; 6 = severely diseased plants) was used to estimate disease severity and a vascular discoloration index (VDI), ranging from 1 to 4 ( 1 = tap-root apparently healthy and white in color; 2 = vascular discoloration only in root system; 3 = brown discoloration of the vascular bundles up to the first stem knot; $4=$ brown discoloration in internodes up to the top of the plant) was used to estimate the severity of vascular bundle discoloration. Finally, the disease index (DI) was calculated as the product of the two above indices (LSI $x$ VDI) and it ranged from 1 to 24 . According to their product value, plants were divided into six DI groups: 1) plants with a product value of $1 ; 2$ ) plants with a value of $2 ; 3$ ) plants with values of 3 to 5 ; 4) plants with values of 6 to 9 ; 5) plants with values of 10 to 15 ; and 6) plants with values of 16 to 24 (Bletsos et al., 1999; see Table 1 for more details). The LSI and VDI were determined for each plant and the DI (Table 1) was calculated for the final production period.

The total and marketable fruit yield was measured for two time intervals: early production period (3-31 July 1998 and 12-29 July 1999) and final harvest (3 July-22 Sept. 1998 and 12 July-9 Sept. 1999). Number and weight of total and marketable fruit weight were determined. Plant height $(\mathrm{cm})$ from the cotyledons to the apex, main stem diameter $(\mathrm{cm})$ at the height of the cotyledons, total biomass $(\mathrm{g})$, aboveground biomass $(\mathrm{g})$, and root biomass $(\mathrm{g})$ were measured. The $\mathrm{pH}$ was measured in $5 \mathrm{~mL}$ of fruit juice using a digital $\mathrm{pH}$ meter (model 196, WTW, Weilheim i. OB, Germany), and the total soluble solids $\left({ }^{\circ} \mathrm{Brix}\right)$ were measured in a few drops of the juice using the digital refactometerATAGO PR-1 (ATAGOCo., Ltd., Tokyo, Japan). Plant infection by $V$. dahliae was verified by isolations from roots and the main stem on potato dextrose agar.

\section{Results}

Success in grafting. The percentage of successfully grafted eggplants on $S$. torvum was $84.4 \%$ and $80.8 \%$ in 1998 and 1999 , re- spectively, while on $S$. sisymbriifolium it was $77.2 \%$ and $74.8 \%$.

Performance of grafted vs. nongrafted plants in fumigated soil; early and late harvest periods. In fumigated soil, all the parameters of vigor, yield, and fruit quality (except mean fruit weight and plant height) during early production in 1998 had significantly higher values for grafted eggplant (Table 2). In contrast, in 1999 the grafted plants on fumigated soil produced lower early yields. In the late production period in fumigated soil, significant differences were observed in root weight, number of marketable fruit, and marketable yield in 1998, while in 1999 only in stem diameter for both grafted treatments compared to nongrafted plants (Table 3 ). The grafted plants on S. torvum compared to nongrafted plants, grown in fumigated soil with methyl bromide (Table 3), were significantly taller in 1999, root weight was higher, and main stem diameter was larger in both years, while the grafted plants on S. sisymbriifolium had significantly higher root weight and main stem diameter in 1999 (Table 3). In fumigated soil, the advantages of the grafted plants were clear in 1998 and variable in 1999.

Performance of grafted vs. nongrafted plants in nonfumigated, inoculated soil; early and late harvest periods. In the infested soil, all the parameters in 1998 had higher values for plants grafted on $S$. torvum than nongrafted plants (Table 2). In 1999 during the early production period on infested soil, significant differences were observed in number of marketable fruit and plant height. In the late production period, however, in the presence of Verticillium the differences were significant for all the measured characteristics in both years (except number of marketable fruits and marketable yield in 1999). Grafting on both rootstocks provided better performance than nongrafted plants grown on infested soil. Averaging over both years, early marketable yield of GST, GSS, and nongrafted plants grown in infested soil was reduced by $29.4 \%$, $36.7 \%$, and $77.9 \%$ compared to plants grown in fumigated soil. Total marketable yield was reduced by $6.9 \%, 20.5 \%$, and $56.8 \%$, respectively. However, none of the qualitative fruit traits ( $\mathrm{pH}$ and ${ }^{\circ}$ Brix) was affected. Their values ranged from 5.70 to 5.96 and from 4.55 to 5.27, respectively. Grafting on GST had higher values for many parameters studied in both

Table 2. Effect of grafting eggplant on verticillium wilt resistant rootstocks (S. torvum and S. sisymbriifolium) compared with nongrafted eggplant, on scion plant height and several fruit and yield parameters, during the early production period of 1998 and 1999, when grown on both soil fumigated with methyl bromide and soil infested with Verticillium.

\begin{tabular}{|c|c|c|c|c|c|c|c|c|c|c|c|c|c|c|}
\hline \multirow[b]{3}{*}{ Grafting on/Year } & \multicolumn{12}{|c|}{ Characteristics } & & \\
\hline & \multicolumn{2}{|c|}{$\begin{array}{c}\text { Total early } \\
\text { yield (g) }\end{array}$} & \multicolumn{2}{|c|}{$\begin{array}{l}\text { Marketable } \\
\text { yield }(\mathrm{g})\end{array}$} & \multicolumn{2}{|c|}{$\begin{array}{l}\text { No. of } \\
\text { fruit }\end{array}$} & \multicolumn{2}{|c|}{$\begin{array}{c}\text { No. of } \\
\text { marketable fruit }\end{array}$} & \multicolumn{2}{|c|}{$\begin{array}{c}\text { Mean wt of } \\
\text { marketable fruit }\end{array}$} & \multicolumn{2}{|c|}{$\begin{array}{l}\text { Mean fruit } \\
\mathrm{wt}(\mathrm{g})\end{array}$} & \multicolumn{2}{|c|}{$\begin{array}{l}\text { Plant } \\
\text { ht }(\mathrm{cm})\end{array}$} \\
\hline & 1998 & 1999 & 1998 & 1999 & 1998 & 1999 & 1998 & $\overline{1999}$ & 1998 & 1999 & 1998 & 1999 & 1998 & $\overline{1999}$ \\
\hline \multicolumn{15}{|c|}{ Fumigated soil } \\
\hline torvum & $2867 \mathrm{a}$ & 993 bc & 2294 a & $894 \mathrm{~b}$ & $20.3 \mathrm{a}$ & $6.0 \mathrm{bc}$ & $14.0 \mathrm{a}$ & $4.5 \mathrm{~b}$ & $159.7 \mathrm{a}$ & $182.3 \mathrm{a}$ & $137.7 \mathrm{ab}$ & $226.5 \mathrm{a}$ & $124 \mathrm{a}$ & $116 \mathrm{ab}$ \\
\hline ium & $2217 \mathrm{~b}$ & $1240 \mathrm{~b}$ & $1516 \mathrm{~b}$ & $1080 \mathrm{~b}$ & $18.3 \mathrm{a}$ & $9.4 \mathrm{a}$ & $10.3 \mathrm{~b}$ & 7.5 & & & b & & $103 \mathrm{ab}$ & $124 \mathrm{a}$ \\
\hline Not grafted & $914 \mathrm{~cd}$ & $1599 \mathrm{a}$ & $722 \mathrm{c}$ & $1469 \mathrm{a}$ & $6.7 \mathrm{~b}$ & $10.5 \mathrm{a}$ & $4.3 \mathrm{~cd}$ & $9.3 \mathrm{a}$ & $136.0 \mathrm{~b}$ & $139.8 \mathrm{bc}$ & $118.3 \mathrm{ab}$ & $130.6 \mathrm{bc}$ & $92 \mathrm{~b}$ & $115 \mathrm{~b}$ \\
\hline \multicolumn{15}{|c|}{ Infested soil } \\
\hline tor & $491 \mathrm{ab}$ & $452 \mathrm{~d}$ & $1848 \mathrm{ab}$ & $404 \mathrm{c}$ & $18.0 \mathrm{a}$ & $2.8 \mathrm{~d}$ & $11.3 \mathrm{ab}$ & $2.0 \mathrm{c}$ & 160.0 & 110. & $140.7 \mathrm{a}$ & & $115 \mathrm{~b}$ & $99 \mathrm{c}$ \\
\hline S. sisybriifolium & $1285 \mathrm{c}$ & $879 \mathrm{c}$ & $863 \mathrm{c}$ & $782 \mathrm{~b}$ & $10.0 \mathrm{~b}$ & $6.3 \mathrm{~b}$ & $6.3 \mathrm{~b}$ & $5.3 \mathrm{c}$ & $125.0 \mathrm{ab}$ & $121.4 \mathrm{~cd}$ & $108.0 \mathrm{~b}$ & $130.0 \mathrm{bc}$ & $86 \mathrm{bc}$ & $99 \mathrm{c}$ \\
\hline Not grafted & $534 \mathrm{~d}$ & $413 \mathrm{~d}$ & $175 \mathrm{~d}$ & $310 \mathrm{c}$ & $6.3 \mathrm{~b}$ & $3.9 \mathrm{~cd}$ & $3.9 \mathrm{~cd}$ & $1.3 \mathrm{~d}$ & $83.3 \mathrm{~b}$ & $96.6 \mathrm{~d}$ & $76.5 \mathrm{c}$ & $90.0 \mathrm{c}$ & $64 \mathrm{~d}$ & $67 \mathrm{~d}$ \\
\hline
\end{tabular}

Means in the same column followed by the same letter are not significantly different $(P \leq 0.05)$ according to Duncan's multiple range test. 
infested and noninfested soil. Total and marketable yield in 1998 decreased significantly on nongrafted as compared to GST when the plants were grown in fumigated or infested soil. Furthermore, root biomass and stem diameter decreased significantly in the control compared to GST. A significant decrease was also observed during the late production period for all parameters studied (except number of marketable fruit and marketable yield in 1999) on the plants grown in infested soil (Table 3 ). Finally, nongrafted and noninfected plants had marketable yield and plant height significantly higher than nongrafted and infected ones in the early production period, while all values were significantly higher (except number of marketable fruit in both years, marketable yield in 1998, and weight of marketable fruit in 1999) in the late production period (Table 3).

Differences in performance between $S$. torvum and S. sisymbriifolium. In fumigated soil, during the early production period, the total early yield, marketable yield, and number of marketable fruit in 1998 had significantly higher values for plants grafted on S. torvum than on S. sisymbriifolium. In 1999, however, significantly higher values for GST were observed for mean fruit weight and for GSS for number of fruit and number of marketable fruit (Table 2). In the late production period, only stem diameter in 1998 and biomass and root biomass in 1999 were significantly higher for plants grafted on S. torvum when compared to GSS. In infested soil and during the early pro- duction period, GST gave significantly higher total early yield, marketable yield, number of fruit, and mean fruit weight in 1998 when compared to GSS, while in 1999 the results were reversed for total early yield, marketable yield, and number of fruit. In the late production period, plants grafted on $S$. torvum produced significantly higher values for biomass and aerial biomass in 1998 and root biomass and height in 1999 when compared to GSS. Root biomass in 1998, however, was significantly higher for plants grafted on $S$. sisymbriifolium. Over the 2 years in early production, plants grafted on S. torvum outyielded the ones grafted on S. sisymbriifolium by $22.8 \%$ and $37.0 \%$ in fumigated and infested soil, respectively, and in late production by $6.3 \%$ and $24.5 \%$, respectively.

Isolations from all plants showed positive results only on the susceptible eggplant scion, whereas the resistant Solanum rootstocks apparently remained free of infection, as evidenced by lack of vascular discoloration and the failure to isolate the pathogen from rootstock vascular tissue. The pathogen occurred at epidemic levels in nongrafted (control) plants, with essentially $96 \%$ and $100 \%$ disease incidence in the early and late production periods, respectively. In addition, the average value of LSI during early production and DI during late production were 3.78 and 5.23, respectively. Grafted plants that were infected by the pathogen generally developed mild symptoms, as indicated by a very low LSI (over years 1.2 and 2.22) and DI (over years 1.55 and 3.38) for GST and GSS, respectively.

The resistance of the grafted plants was indicated by the increased percentage of the healthier plants observed in the grafted group as compared to the nongrafted ones (Table 4). The percentage of the severely diseased plants for GST, GSS, and nongrafted were $0.0 \%, 22.9 \%$, and $79.0 \%$, respectively. Healthy plants were observed among nongrafted plants only in the early production period.

\section{Discussion}

The high percentage of successful grafting observed for both Solanum species with no change in fruit quality indicated that both rootstocks are suitable for eggplant grafting. The yield advantage of the grafted plants was obvious when grown on infested soil (Tables 2 and 3 ). Yet, the advantage of the grafted plants was not justified in 1999 when the plants were grown in pathogen-free soil. The taller plants and the larger main stem diameter of the grafted plants were attributed to the vigorous root system (Table 3) of the rootstock. Similarly, the increased yield of grafted plants is believed to be due to enhanced water and mineral uptake (Lee, 1994). According to Young (1989), the rootstock's vigorous root system is often capable of absorbing water and nutrients more efficiently than scion roots. Thus, the significantly higher marketable yield of the plants grafted on $S$. torvum and $S$. sisymbriifolium

Table 3. Effect of grafting eggplant on verticillium wilt resistant rootstocks (S. torvum and S. sisymbriifolium) compared with nongrafted eggplant on plant parameters and fruit yield quality, during the final harvest period in 1998 and 1999, when grown on both soil fumigated with methyl bomide and soil infested with Verticillium.

\begin{tabular}{|c|c|c|c|c|c|c|c|c|c|c|c|c|c|c|c|c|}
\hline \multirow[b]{3}{*}{ Grafting on/Year } & \multicolumn{16}{|c|}{ Characteristics } \\
\hline & \multicolumn{2}{|c|}{$\begin{array}{l}\text { Marketable } \\
\text { yield }(\mathrm{g})\end{array}$} & \multicolumn{2}{|c|}{$\begin{array}{c}\text { No. of } \\
\text { marketable fruit }\end{array}$} & \multicolumn{2}{|c|}{$\begin{array}{l}\text { Wt of marketable } \\
\text { fruit }(\mathrm{g}) \\
\end{array}$} & \multicolumn{2}{|c|}{$\begin{array}{l}\text { Biomass } \\
(\mathrm{g})\end{array}$} & \multicolumn{2}{|c|}{$\begin{array}{c}\text { Aerial } \\
\text { biomass }(\mathrm{g})\end{array}$} & \multicolumn{2}{|c|}{$\begin{array}{c}\text { Root } \\
\text { biomass }(\mathrm{g})\end{array}$} & \multicolumn{2}{|c|}{$\begin{array}{c}\text { Stem } \\
\text { diam }(\mathrm{cm})\end{array}$} & \multicolumn{2}{|c|}{$\begin{array}{l}\mathrm{Ht} \\
(\mathrm{cm})\end{array}$} \\
\hline & 1998 & 1999 & 1998 & 1999 & 1998 & 1999 & 1998 & 1999 & 1998 & 1999 & 1998 & 1999 & 1998 & 1999 & 1998 & 1999 \\
\hline \multicolumn{17}{|c|}{ Fumigated soil } \\
\hline to & $60 \mathrm{a}$ & $12 \mathrm{a}$ & $29.3 \mathrm{a}$ & 12 & $158 \mathrm{a}$ & $161 \mathrm{a} 2$ & $2090 \mathrm{ab}$ & $2514 \mathrm{a}$ & $1923 a b$ & 22 & $a b$ & 28 & $6 \mathrm{a}$ & $\mathrm{a}$ & $154 \mathrm{a}$ & $165 \mathrm{a}$ \\
\hline 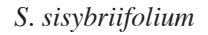 & 3979 a & $108 \mathrm{a}$ & $26.3 \mathrm{a}$ & $15.0 \mathrm{a}$ & $157 \mathrm{a}$ & $157 \mathrm{a}$ & $1995 \mathrm{ab}$ & 193 & $1798 \mathrm{~b}$ & 171 & $198 \mathrm{a}$ & $171 \mathrm{~cd}$ & $2.36 \mathrm{c}$ & $2.80 \mathrm{a}$ & $137 \mathrm{ab}$ & $156 \mathrm{ab}$ \\
\hline Not grafted & $1601 \mathrm{~b}$ & $2222 \mathrm{a}$ & $9.7 \mathrm{~b}$ & $13.0 \mathrm{ab}$ & $153 \mathrm{a}$ & $143 a b$ & $1960 \mathrm{~b}$ & $1693 \mathrm{~b}$ & $1838 \mathrm{ab}$ & $1543 \mathrm{~b}$ & $122 \mathrm{c}$ & $150 \mathrm{~d}$ & $2.60 \mathrm{bc}$ & $2.26 \mathrm{~b}$ & $145 \mathrm{ab}$ & $136 \mathrm{bc}$ \\
\hline \multicolumn{17}{|c|}{ Infested soil } \\
\hline & $19 \mathrm{a}$ & $10 \mathrm{ab}$ & $30.0 \mathrm{a}$ & $7 .($ & $159 \mathrm{a}$ & $152 \mathrm{a} 2$ & $2327 \mathrm{a}$ & $2109 a b$ & & & $134 \mathrm{bc}$ & & $3.06 \mathrm{a}$ & $2.60 \mathrm{ab}$ & $129 \mathrm{~b}$ & $156 \mathrm{ab}$ \\
\hline sisybriifolium & 3549 a & $1291 \mathrm{ab}$ & $23.0 \mathrm{a}$ & $8.6 a b$ & $149 \mathrm{a}$ & $150 \mathrm{a}$ & $1192 \mathrm{c}$ & $2357 \mathrm{a}$ & $1508 \mathrm{c}$ & 209 & $183 \mathrm{a}$ & $171 \mathrm{~cd}$ & $2.80 \mathrm{ab}$ & $2.30 \mathrm{~b}$ & $137 \mathrm{ab}$ & $133 \mathrm{c}$ \\
\hline Not grafted & $882 \mathrm{~b}$ & $768 \mathrm{~b}$ & $6.7 \mathrm{~b}$ & $6.3 \mathrm{~b}$ & $96 \mathrm{~b}$ & $119 \mathrm{~b}$ & $692 \mathrm{~d}$ & $789 c$ & $613 \mathrm{~d}$ & $719 c$ & $79 \mathrm{~d}$ & $70 \mathrm{e}$ & $1.47 \mathrm{~d}$ & $1.76 \mathrm{c}$ & $86 \mathrm{c}$ & $98 \mathrm{~d}$ \\
\hline
\end{tabular}

Means in the same column followed by the same letter are not significantly different $(P \leq 0.05)$ according to Duncan's multiple range test.

Table 4. Distribution of the eggplants in each grade of leaf symptom index and disease index during a) the early production period and b) at the final production period during the 2 years (1998 and 1999), when grafted on S. torvum and S. sisymbriifolium or not grafted.

\begin{tabular}{|c|c|c|c|c|c|c|c|c|c|c|c|c|c|c|}
\hline \multirow[b]{4}{*}{ Grafting on /Year } & \multicolumn{13}{|c|}{ Leaf symptom index in the early production period } & \multirow[b]{2}{*}{$\overline{\mathrm{X}}$} \\
\hline & 1 & 2 & 3 & 4 & 5 & 6 & $\overline{\mathrm{X}}$ & 1 & 2 & 3 & 4 & 5 & 6 & \\
\hline & \multicolumn{13}{|c|}{ Percentage of plants in each grade of leaf symptom index } & \\
\hline & \multicolumn{7}{|c|}{1998} & \multicolumn{6}{|c|}{1999} & \\
\hline S. torvum & $86.7 \mathrm{a}$ & $10.0 \mathrm{a}$ & $3.3 \mathrm{a}$ & $0.0 \mathrm{a}$ & $0.0 \mathrm{a}$ & $0.0 \mathrm{a}$ & $1.27 \mathrm{c}$ & $57.1 \mathrm{a}$ & $28.6 \mathrm{a}$ & $0.0 \mathrm{~b}$ & $14.3 \mathrm{a}$ & $0.0 \mathrm{a}$ & $0.0 \mathrm{~b}$ & $1.13 \mathrm{c}$ \\
\hline S. sisymbriifolium & $56.7 \mathrm{a}$ & $10.0 \mathrm{a}$ & $6.7 \mathrm{a}$ & $21.4 \mathrm{a}$ & $3.3 \mathrm{a}$ & $0.0 \mathrm{a}$ & $2.47 \mathrm{~b}$ & $38.1 \mathrm{a}$ & $28.6 \mathrm{a}$ & $20.8 \mathrm{a}$ & $14.4 \mathrm{~b}$ & $0.0 \mathrm{a}$ & $0.0 \mathrm{~b}$ & $1.97 \mathrm{~b}$ \\
\hline \multirow[t]{4}{*}{ Not grafted } & $3.3 \mathrm{~b}$ & $13.3 \mathrm{a}$ & $30.0 \mathrm{a}$ & $50.0 \mathrm{a}$ & $3.4 \mathrm{a}$ & $0.0 \mathrm{a}$ & $3.93 \mathrm{a}$ & $4.8 \mathrm{~b}$ & $14.3 \mathrm{a}$ & $28.6 \mathrm{a}$ & $38.0 \mathrm{a}$ & $0.0 \mathrm{a}$ & $14.3 \mathrm{a}$ & $3.63 \mathrm{a}$ \\
\hline & \multicolumn{13}{|c|}{ Disease index in the late production period } & \\
\hline & 1 & 2 & 3 & 4 & 5 & 6 & $\overline{\mathrm{X}}$ & 1 & 2 & 3 & 4 & 5 & 6 & $\overline{\mathrm{X}}$ \\
\hline & \multicolumn{13}{|c|}{ Percentage of plants in each grade of disease index } & \\
\hline Grafting on / Year & \multicolumn{7}{|c|}{1998} & \multicolumn{6}{|c|}{1999} & \\
\hline S. torvum & $86.7 \mathrm{a}$ & $0.0 \mathrm{a}$ & $0.0 \mathrm{a}$ & $13.3 \mathrm{a}$ & $0.0 \mathrm{~b}$ & $0.0 \mathrm{~b}$ & $1.40 \mathrm{c}$ & $57.1 \mathrm{a}$ & $19.1 \mathrm{a}$ & $19.1 \mathrm{a}$ & $4.7 \mathrm{~b}$ & $0.0 \mathrm{~b}$ & $0.0 \mathrm{~b}$ & $1.70 \mathrm{c}$ \\
\hline S. sisymbriifolium & $36.7 \mathrm{a}$ & $3.3 \mathrm{a}$ & $23.3 \mathrm{a}$ & $10.0 \mathrm{a}$ & $13.3 \mathrm{a}$ & $13.4 \mathrm{~b}$ & $3.00 \mathrm{~b}$ & $4.8 \mathrm{~b}$ & $0.0 \mathrm{~b}$ & $33.3 \mathrm{a}$ & $42.8 \mathrm{a}$ & $14.3 \mathrm{ab}$ & $4.8 \mathrm{~b}$ & $3.77 \mathrm{~b}$ \\
\hline Not grafted & $0.0 \mathrm{~b}$ & $0.0 \mathrm{a}$ & $3.3 \mathrm{a}$ & $10.0 \mathrm{a}$ & $26.7 \mathrm{a}$ & $60.0 \mathrm{a}$ & $5.43 \mathrm{a}$ & $0.0 \mathrm{~b}$ & $0.0 \mathrm{~b}$ & $4.8 \mathrm{a}$ & $23.8 \mathrm{a}$ & $33.3 \mathrm{a}$ & $38.1 \mathrm{a}$ & $5.03 \mathrm{a}$ \\
\hline
\end{tabular}

Means in the same column followed by the same letter are not significantly different $(P \leq 0.05)$ according to Duncan's multiple range test. 
and grown in fumigated soil as compared to the nongrafted ones observed in 1998 in the present study, could be attributed to their higher root biomass (Table 3). In addition, the reduction of marketable yield (early and total) from plants grafted on S. torvum was $29.3 \%$ and $8.7 \%$, while the ones grafted on $S$. sisymbriifolium exhibited a yield reduction of $52.8 \%$ and $42.3 \%$. This supports the idea that $S$. torvum is markedly resistant, while $S$. sisymbriifolium is less resistant to verticillium wilt (Bletsos et al., 1998a). However, germination was delayed $(\approx 20$ d) when eggplants were grafted on $S$. torvum, and the early growth before grafting was low due to the very small seeds. Tachibana (1994) reported that the plants grafted on $S$. torvum sometimes suffer from $\mathrm{Mg}$ deficiency mainly due to the low ability of the stock roots to absorb $\mathrm{Mg}$ ions.

The fact that the grafted plants produced better results than the nongrafted ones when grown on infested soils indicates the potential economic value of growing grafted plants for the growers. Grafting is extremely laborious and time consuming, and growers would like to reduce the labor input required. Grafting robots have been developed for grafting eggplant, tomato, and pepper (Kurata, 1994; Oda, 1995). Robot grafting is $\approx 10$ times faster than conventional hand grafting. Eggplant grafted by robot produced a similar fruit yield to that of plants grafted by conventional methods (Oda et al., 1997). Since grafting gives increased disease tolerance and vigor to crops, it should be useful for the low-input sustainable horticulture of the future (Table 4). In conclusion, grafting of eggplant on either of the two wild species had a positive effect on the growth, production, and observed disease incidence.

\section{Literature Cited}

Alconero, R., W. Robinson., B. Dicklow, and J. Shail. 1988. Verticillium wilt resistance in eggplant, related Solanum species, and interspecific hybrids. HortScience 23:388-390.

Bletsos, F.A., C.C. Thanassoulopoulos, and D.G. Roupakias. 1997a. The susceptibility of Greek eggplant varieties to verticillium wilt. Acta Hort. 462:211-216

Bletsos, F.A., C.C. Thanassoulopoulos, and D.G. Roupakias. 1997b. Level of resistance to Verticillium dahliae of an interspecific $\mathrm{F}_{1}$ hybrid (Solanum melongena $\mathrm{x}$ Solanum torvum). J. Genet. Breeding 51:69-73.

Bletsos, F.A., C.C. Thanassoulopoulos, and D.G. Roupakias. 1998a. Sensitivity of two Greek eggplant varieties and the wild species Solanum sisymbriifolium Lam. to verticillium wilt. J. Genet. Breeding 52:99-102.

Bletsos, F.A., C.C. Thanassoulopoulos, and D.G. Roupakias. 1999. Water stress and verticillium severity on eggplant (Solanum melongena L.). J. Phytopathol. 147:243-248.

Ferrari, V. 1998. Fusarium and root knot nematodes, two adversaries of melon which are difficult to control chemically. Informatore-AgrarioSupplemento 54(3):48-50. (Abstr.)

Ginaux, G. and P. Douple. 1985. Greffe par perforation laterale de l'aubergine et de la tomate. Revue Horticole 253:29-34.

Ginaux, G., P. Douple., C. Guimbard, and J.M. Lefebvre. 1979. Tomato grafting, a method of controlling soil pests. II. Pepinieristes-Horticulteurs-Maraichers 194:19-29.

Kalloo, G. 1993. Eggplant (Solanum melongena L.), p. 587-604. In: G. Kalloo and B.O. Bergh (eds.). Genetic improvement of vegetable crops. Pergamon Press, Oxford, U.K.

Klose, P., H.J. Hertwig, and K. Kuhnert. 1980. Longterm experiments with grafting of greenhouse cucumbers on Cucurbita ficifolia in the LPG "Fruhgemusezentrum Dresden." Gartenbau
27(11):330-332. (Abstr.)

Kurata, K. 1994. Cultivation of grafted vegetables II. Development of grafting robots in Japan. HortScience 29:240-244.

Lee, J.M. 1994. Cultivation of grafted vegetables I. Current status, grafting methods, and benefits. HortScience 29:235-239.

Lockwood, J.L., O.L. Yoder, and M.K. Bente. 1970. Grafting eggplants on resistant rootstocks as a possible approach for control of verticillium wilt. Plant Dis. Rep. 54:846-848.

Nicklow, C.W. 1983. The use of recurrent selection in efforts to achieve Verticillium resistance in eggplant. HortScience 18:600.

O’Brien, M. 1983. Evaluation of eggplant accessions and cultivars for resistance to verticillium wilt. Plant Dis. Rep. 67:763-764.

Oda, M. 1995. New grafting methods for fruit-bearing vegetables in Japan. Jarq 29:187-194.

Oda, M., K. Okada, H. Sasaki, S. Akazawa, and M. Sei. 1997. Growth and yield of eggplants grafted by a newly developed robot. HortScience $32: 848-849$

Ristaino, J.B. and W. Thomas. 1997. Agriculture, methyl bromide, and the ozone hole: Can we fill the gaps? Plant Dis. 81:964-977.

Sakata, Y., T. Nishio, and S. Mon'ma. 1989. Resistance of Solanum species to verticillium wilt and bacterial wilt, p. 177-181. Proc. Eucarpia VIIth Mtg. Genet. Breeding on Capsicum and Eggplant, 27-30 June 1989, Kraguievac, Yugoslavia.

Tachibana, S. 1994. Eggplant, p. 63-66. In: Organizing Comm. XXIVth Intl. Hort. Congr. (ed.). Horticulture in Japan.

Wheeler,W.B. and N.S. Kawar. 1997. Environmental hazards fumigants: The need for safer alternatives. Arab J. Plant Protection 15:154-162.

Young, E. 1989. Cytokinin and soluble carbohydrate concentrations in xylem sap of apple during dormancy and bud break. J. Amer. Soc. Hort. Sci. 114:297-300. 